\title{
Catheter induced spinal epidural abscess in dialysis patients: A Systematic review of descriptive studies
}

\author{
Mohammed Zuber ${ }^{1}$, BH Vidhyashree ${ }^{1}$, Shifa Taj ${ }^{2}$, Rajesh Venkatraman ${ }^{3}$, BP Sathish \\ Kumar $^{1}$, and Nihala Jabeen ${ }^{4}$ \\ ${ }^{1}$ Sri Adichunchanagiri College of Pharmacy \\ ${ }^{2}$ Saradavilas College of Pharmacy \\ ${ }^{3}$ Adichunchanagiri University \\ ${ }^{4}$ Markaz Unani Medical College
}

May 28, 2021

\begin{abstract}
ABSTRACT Purpose: Recently, there is an increased number of reports being published on catheter-induced spinal epidural abscess (SEA). This review aims to identify and critically evaluate all the descriptive studies that report the SEA due to catheterization and its presentation, diagnosis, management, and outcomes. Methodology: A literature search was performed in the PubMed database using MeSH terms "epidural abscess" AND "renal dialysis" from inception to January 2021 without any language restriction. Google Scholar, grey literature databases (GreyNet. OpenGrey, Grey literature Report, BIOSIS Previews), and the bibliographic search of included studies were carried out to find the additional studies. Descriptive studies describing the SEA induced by catheter usage were included in the review. Study selection, data extraction, and quality assessment were conducted by two independent reviewers any disagreement was resolved by discussing with the third reviewer. Results: Data of 6 studies were retrieved for this review which includes 11 patients ( 5 females and 6 males) aged from 26 to 79 years old. The most common patient's presentation was back pain, high-grade fever, quadriparesis, neck pain, drowsy, and altered mental status. The most common isolated microorganism from the blood and catheter tip was Methicillin-resistant Staphylococcus aureus. The most common findings in all the patients were elevated erythrocyte sedimentation rate and leucocyte count. Conclusion: Clinicians must be aware of the possibilities of SEA initiated by catheter usage to prevent further consequences. Aggressive antibiotic therapy along with surgical intervention are the cornerstones in the management of SEA. Early diagnosis and initiation of treatment are important factors that decide the mortality and morbidity in patients with SEA. Keywords: Catheter; Dialysis; Spinal epidural abscess; Systematic review; Case report Protocol registration: International Prospective Register for Systematic Reviews (PROSPERO) ID: CRD42021233375
\end{abstract}

\section{Hosted file}

Manuscript_SEA.docx available at https://authorea.com/users/410038/articles/523976-catheterinduced-spinal-epidural-abscess-in-dialysis-patients-a-systematic-review-of-descriptivestudies

\section{Hosted file}

Figure 1_PRISMA Flow diagram.docx available at https://authorea.com/users/410038/articles/ 523976-catheter-induced-spinal-epidural-abscess-in-dialysis-patients-a-systematicreview-of-descriptive-studies

\section{Hosted file}


Table 1_Characteristics of studies (1).docx available at https://authorea.com/users/ 410038/articles/523976-catheter-induced-spinal-epidural-abscess-in-dialysis-patientsa-systematic-review-of-descriptive-studies

\section{Hosted file}

Table 2_Patient and Treatment characteristics.docx available at https://authorea.com/users/ 410038/articles/523976-catheter-induced-spinal-epidural-abscess-in-dialysis-patients-asystematic-review-of-descriptive-studies

\section{Hosted file}

Table 3_Clinical presentation.docx available at https://authorea.com/users/410038/articles/ 523976-catheter-induced-spinal-epidural-abscess-in-dialysis-patients-a-systematicreview-of-descriptive-studies

\section{Hosted file}

Table 4_Clinical diagnosis.docx available at https://authorea.com/users/410038/articles/ 523976-catheter-induced-spinal-epidural-abscess-in-dialysis-patients-a-systematicreview-of-descriptive-studies

\section{Hosted file}

Table 5_Management.docx available at https://authorea.com/users/410038/articles/523976catheter-induced-spinal-epidural-abscess-in-dialysis-patients-a-systematic-review-ofdescriptive-studies 